\title{
HISTORICAL POLITICS, MELTED CITIZENSHIP AND EDUCATION ABOUT THE HOLOCAUST INTERVIEW WITH JOLANTA AMBROSEWICZ-JACOBS
}

Interview conducted by Anna Odrowąż-Coates

\section{JOLANTA AMBROSEWICZ-JACOBS ${ }^{1} \&$ ANNA ODROWĄŻ-COATES ${ }^{2}$}

${ }^{1}$ UNESCO Chair for Education about Holocaust, Jagiellonian University, Garbarska 7a, 31-131 Kraków, Poland. ORCID: 0000-0001-7741-9756,Email: jolanta.ambrosewicz-jacobs@uj.edu.pl

${ }^{2}$ UNESCO Janusz Korczak Chair in Social Pedagogy, The Maria Grzegorzewska University, Szczęśliwicka 40, 02-353 Warszawa, Poland. ORCID: 0000-0002-2112-8711, Email: acoates@aps.edu.pl

(AOC): Dear Professor Ambrosewicz-Jacobs, you are an icon for education about the Holocaust in Poland, you are very well regarded abroad and well known for that reason. I will start with some simple questions to get our conversation going. First question:

Would you say that there are challenges in the preservation of memory about the Holocaust and challenges for the preservation of historic objectivity?

(JA-J): Yes, do you mean the determinants, the factors that may have an impact on objectivity? If so, this question can be approached from various angles. In my opinion not only someone who is researching empirically, memory of the Holocaust in Poland in context of course and in comparative perspective, but also in my opinion, the key persons to work with are the teachers, educators and non-governmental activists, the human resources so to say, who are the carriers of memory. It is not enough to produce historiography only, books, but also it is very important to disseminate research and have impartial academic dialogue and as we know, my colleagues from the Polish Centre for Holocaust Research at the Polish Academy of Warsaw are under a major attack right now for their very credible and valid research. The main factors are social actors involved in carrying on the memory of the Holocaust and knowledge of the Holocaust. I am speaking on the basis of my 14-year experience of organizing Summer Insti- 
tutes teaching about the Holocaust for Polish and also Ukrainian educators. Teachers from Moscow and Azerbaijan also attended the institute twice. We now work only with graduates, because of the demand among our graduates to have more opportunities to develop not only knowledge, but skills and competences. The key factor, especially when we think about the accuracy of transmitting knowledge and carrying knowledge, the key factors are people, educators who care. Very often they do it from the need of their heart and they are not supported by educational systems. Often, not always, but often, they are not supported by the administration of the schools, parents, and governmental agencies. Therefore, educators need support, they need very clear message that the work that they are doing is important for future generations. The second factor is the quality of the research and this is very important because it is currently challenged in Poland and is being manipulated by historical politics.

Even the facts, if they are present in a textbook for example, facts related to the historiography of the Holocaust, they can be presented in a certain context that is very misleading for students. Therefore, accuracy is essential. The third is the interconnec tion of various social actors in school systems, civil society and self-government. Often, they work in isolation. Public schools seldom cooperate with local governments, ministries or units responsible for memorial sites. There is not enough connection between users of memorial sites, schools and non-governmental organizations. So this is an obstacle to carry the memory of the Holocaust. Because, if those social actors work in isolation, then obviously they are weaker. Of course, I'm expressing a very general opinion, because there are exceptions and the Auschwitz-Birkenau Museum is certainly one example, or the State Museum at Majdanek. Just to mention two of them, two of the former concentration and death camps in Poland. These two are connected with schools and non-governmental organizations, but in Poland we have many more memorial sites and there is definitely not enough cooperation and mutual support. Those are major determinants, factors, which are crucial for historiographical accuracy and carrying memory of the Holocaust.

(AOC): Are you familiar with the term 'public history'?

(JA-J): Public history - yes.

(AOC): So, you think that perhaps because the new generation did not have direct contact with the events of WW2, public history may be a means or the way to carry the memory of what happened during the Holocaust.

(JA-J): Yes, but also it has its limitations. The limitations depend on how the media represent the history. They can represent the history in public spaces in very distorted ways. This is what we experience currently in Poland and in other countries. There is an issue in the Baltic states for example, in Ukraine and in Hungary as well. Therefore,
Poland is not an isolated case amongst countries of Central and Eastern Europe. What has been happening right now, I would call it major distortions of history in public space. Public history is also connected to post-memory. This is a term used by Marianne Hirsch, which I think is worth mentioning, because this is the memory of events that we do not have direct contact with, which is transmitted through family and his torical narratives, also transmitted through textbooks and what teachers have to say in a class. It has really affected the debate and so many other various factors. Distortions to memory are the biggest dangers. Conflicts of memory as well. The public space has many conflicts of memory, which are not perceived as such; as conflicts. They are perceived as narratives that are right or wrong and that clash with one another.

(AOC): If you were to reflect on who stands behind this kind of unsettling distortions and conflicts, would you be able to identify any kind of social force or a lobby?

(JA-I): I think politicians, mainly politicians, because they instrumentalise public opinion. Trying to gain votes in a very cynical way. I would say this is a very soft and easy ground to be manipulated in Poland, because of the past and the conflicts that occurred in the past, directly related to the memory of the Holocaust. Poland as it turned out, did not work this through. I am using a Freudian term, which was adapted by Dominick LaCapra. Poland didn't work through the very difficult facts, related to the past, related to the Holocaust, namely the involvement of some individuals and groups in collaborations. New historiography revealing these facts causes very uncomfortable feelings, because we do not know how our great grandparents or other ancestors might have behaved. Questions were never asked of our ancestors when they lived, because there is fear and I think everybody has this fear. Therefore, even if we do remember the family narratives, sometimes they are also distorted because it was too difficult to admit fear. For example, to admit fear of helping Jews. Our ancestors also witnessed some very cruel behaviour of some of our neighbours or some partisans and even the rescuers. These facts are very well documented actually and also young historians, young PhD students work on these issues. Their methodology is correct and despite this very good methodology, the facts that they discovered are denied. Because their research cause conflicts and many people are afraid in general of conflicts revealed by new historiography, between official narratives of being a nation of martyrs, rescuers and heroes contradicted by new discoveries of microhistory. They do not know how to deal with emerging conflicts of memory of the Holocaust and only a few people are prepared to admit that yes - someone in my family was a shmaltsovnik (SZMALCOWNIK), not a rescuer, but someone who denounced Jews. It is very seldom that someone is able to admit to this. However, there are few examples, very rare ones and I think that our society does not want to think about this. Another problem is rejecting; rejecting reflection and dealing with the past of the Holocaust. So many people think that it is too much. Too much talking about the genocide of Jews and we also experience secondary antisemitism, being tired of thinking, speaking 
and reading about the Holocaust. Coming back to your first question, I think that we need to work on several levels to counteract these conflicts or even to fight the wars of memories. This has to be done first as individuals, then at a group level, national level and intergovernmental level. There should be cooperation or even connection between those levels. I do not see these connections actually. Often what is apparent at an intergovernmental level, is not reflected at the national level. What I mean is, the commitment of Poland and another states of Central-Eastern Europe, political commitments to support research, education and commemoration of the Holocaust, that were expressed in the Stockholm Declaration in 2000. Poland is the member country of the political organization IHRA - The International Holocaust Remembrence Alliance since 1999. But the political committmens resulting from the membership in the IHRA are not transmitted to the national level, through ministry of education There is not enough state support for education about the Holocaust. On the contrary, teachers are afraid to teach about the collaboration of individual Poles and groups (for examples partisans) in the Holocaust, because they may be denounced, they can have problems. Therefore, the whole picture is very complicated.

(AOC): Do you think that there is some mediating factor in the fact that the Jewish population of Poland were actually Polish citizens? So, for example, regarding statistics about mass murders and ghettoization, they refer to both the Polish citizens and the Polish citizens of Jewish faith at the same time? It strikes some people as a bit strange that we make this distinction all the time, of course a distinction made by Hitler, who based his campaign on the extermination of minorities, but Jews were still people of Poland, they had Polish citizenship, they lived and worked in Poland, they had rights guaranteed by the constitution etc.

(JA-J): Absolutely, but this view is not incorporated. This is the whole problem. The Holocaust, even if it is taught in schools and is mandated, it still depends on teachers, how much they want to teach about it. How much they talk about these historical facts, whether they silence it or use interesting projects in their teaching to discuss it. Therefore, the quality of Holocaust education is up to teachers. Even when it is taught, it is not taught in a proper way, that the suffering of Polish Jews was the suffering of Polish citizens. And not all non-Jewish Polish citizens were condemned to death. There are many exceptions, but the dominant view is that 'this is something that happened to 'Them' not to 'Us'. The Holocaust has happened to Jews and the concept of citizenship in this view is dismantled and disappears. Poles in general have a problem with the concept of citizenship. They think in national or ethnic terms, through an individual level to group mentality. So, the concept is that this is something that happened to 'Them'. We Poles, we have different historical narrative about what hap pened to 'Us' during WW2. Therefore, the Holocaust is not really a part of the history of our country - Poland. And this is a paradox, because it is in the history of Poland, but it is not viewed and not represented as such.
Thinking about resources, I think it is down to the school system and very early education, as there is a growing tendency, a growing trend to speak about us as a national group and about minorities as 'Them'. These divisions create a very exclusive vision of history which has impact on historical consciousness and collective memory of the Holocaust. It is still something that happened to 'Them' not to our co-citizens.

(AOC): Thank you for sharing your insightful knowledge and experience with our readers.

(JA-J): My pleasure, these were very good questions.

19th of March 2019

FUNDING: This research received no external funding.

CONFLICTS OF INTEREST: The authors declare no conflict of interest.

\section{BIOGRAPHICAL NOTE}

Jolanta Ambrosewicz-Jacobs is a researcher at UNESCO Chair for Education about Holocaust, and professor in cultural studies at the Jagiellonian University in Kraków, Poland.

Anna Odrowąż-Coates is the chairholder at UNESCO Janusz Korczak Chair in Social Pedagogy, and professor in pedagogy at the Maria Grzegorzewska University in Warsaw, Poland.

OPEN ACCESS: This article is distributed under the terms of the Creative Commons Attribution Noncommercial License (CC BY-NC 4.0) which permits any noncommercial use, and reproduction in any medium, provided the original author(s) and source are credited. 
